\begin{tabular}{lr}
\hline \multicolumn{1}{c}{ D Y N A M I C E C O N O M E T R I C } & M O D E S \\
DOI: http://dx.doi.org/10.12775/DEM.2016.010 & Vol. 16 (2016) 165-187 \\
\hline $\begin{array}{l}\text { Submitted November 30, 2016 } \\
\text { Accepted December 28, 2016 }\end{array}$ & ISSN (online) 2450-7067 \\
ISSN (print) 1234-3862
\end{tabular}

Elżbieta Szulc*, Dagna Wleklińska, Karolina Górna

\title{
The Share of European Economies in the Process of Convergence of Long-term Interest Rates in the EU in the Period of 2006-2016
}

\begin{abstract}
A b s t r a c t. The paper refers to convergence of interest rates of ten-year government bonds emitted by EU countries. It is an attempt to assess the participation of particular economies in this process using the so-called vertical convergence. The primary tools of analysis were panel data models with fixed effects, including models that consider the links among economies, quantified by using a distance matrix between indicators of fiscal stability comprehended as the share of public debt in GDP. The analysis was conducted for the 27 members of the EU in the period between January 2006 and November 2016.
\end{abstract}

K e y w o r d s: long term interest rates; process of convergence; fiscal stability; panel data models; matrix of economic connections.

J E L Classification: C10; C23; C58; E43.

\section{Introduction}

According to the concept of fiscal stability, the value of public debt should be maintained at the level that will provide the opportunity to minimise the negative effects of its occurrence and will not impede the government's tasks implemented to stabilise the economy (Buiter, 2006, p. 2; Marchewka-Bartkowiak, 2008, p. 55). Referring to the French economist, O. J. Blanchard, a stable fiscal policy occurs when it effectively aims to re-

\footnotetext{
"Correspondence to: Elżbieta Szulc, Nicolaus Copernicus University, Faculty of Economic Sciences and Management, 13A Gagarina Street, 87-100 Toruń, Poland, e-mail: eszulc@umk.pl

(C) 2016 Nicolaus Copernicus University. All rights reserved. http://www.dem.umk.pl/dem
} 
duce the ratio of public debt to gross domestic product. Therefore, a longterm debt growth rate should not exceed the height of interest rates, while the debt ratio, measured by the ratio of public debt to gross domestic product, should not be higher than the difference between the rate of economic growth and long-term interest rates. Thus, a conclusion arises that an increase in the government spending intended to support the economic situation in the country must be later offset by actions aimed at achieving fiscal stability by reducing the ratio of public debt to GDP (Blanchard, 1990, p. 13).

Narrowing disparities among long-term interest rates that ensure fiscal stabilisation is identified with one of the most important dimensions of convergence processes, which are considered in relation to European economies. The fundamental theory that should be used to explain the mechanism of European integration and also one of its components, the monetary integration, is the theory of optimum currency areas. According to it, one of the main factors that lead to fluctuations in the exchange rate is the interest rate differential. Regarding the fact that a monetary union operates in the territory of the Old Continent, those disparities may lead to asymmetric shocks. The monetary policy which is common to the member countries does not constitute an effective tool for leveling the risk and consequences of such shocks, and, therefore, their appearance may constitute a real threat to the stability of the monetary union. The theory of convergence points to key areas of similarity between particular economies and thus can help prevent an occurrence of the said shocks and ensure stabilisation of the exchange rate. It is particularly important that the process of proximity of interest rates is accompanied by fiscal convergence identified with the harmonisation of fiscal policies of the members of the EU, because an increase in the debt also leads to an escalation in the premium related to the growing risk of insolvency of the issuer, which is the main component of interest rates (Pełka, 2008, p. 63-71).

Long-term interest rates as a macroeconomic aggregate not only reflect country-specific market factors which determine the nominal cost of the credit, for example, those connected with the rate of increase in prices or inflation expectations, but also indicate the manner of conducting and the quality of economic policy.

The contemporary global financial crisis has revealed weaknesses in the functioning of the European Union, highlighting the need to reform its economic and institutional mechanisms. The fiscal rules defined in the Maastricht Treaty and the complementary Stability and Growth Pact have proven ineffective. However, the insufficient fiscal discipline in many economies 
was not the reason but rather a consequence of the contemporary crisis with the underlying deep structural differences between European economies. The increasing integration of financial markets and a common monetary policy aimed at maintaining relatively low and often negative interest rates in peripheral European countries, led to a further deepening of the existing differences.

The existing literature confirms an occurrence of convergence processes of long-term interest rates during the period of preparation of particular countries to adopt the common currency and introduce it into circulation (Adam et al., 2002; Pagano and von Thadden, 2004). As a consequence of maintaining stable exchange rates the possibility of devaluation of individual currencies in order to increase the competitiveness of the economy was eliminated, and the elimination of an exchange rate risk premium led to a reduction of discrepancies in terms of profits from bonds issued by countries belonging to the euro area. The vision of a common monetary policy required an introduction of preparatory mechanisms, resulting in an anchoring of inflation expectations. On the other hand, thanks to the common pursuit of the Maastricht criteria as well as restrictions on fiscal policy, credit risk was maintained at a relatively low level (Baele, 2004, p. 38; Lane, 2012, p. 1).

However, in the recent period, the results of empirical analyses provide evidence that following the outbreak of the global financial crisis, bonds issued by European economies are no longer substitutes for each other. The search for the causes of the divergence of long-term interest rates was the subject of an empirical analysis conducted, inter alia, by Attinasi et al. (2009) and Klepsch, Wollmershäuser (2011). A partial justification for the differences in the spreads of the yield of government bonds in the European Union rests in the transfer of the credit risk from financial institutions to governments which were providing them with the financial aid (Afonso et al., 2015). Along with the intensification of the European debt crisis, in fear of a growing risk investors restructured their portfolios by deciding to invest in safer instruments that showed greater liquidity, thus leading to a growth in the divergence between the spreads of government bonds (Barrios et al., 2009).

Given the large diversity of European economies that leads us to believe that in the group of the countries that co-create the European Union there are economies that have both a destimulating and stimulating effect on the process of convergence of long-term interest rates, the inference based on the classical model of $\beta$ convergence, which is the most popular method of analysis of this phenomenon, may lead to erroneous conclusions (Nowak, 2007, p. 77-78). Among the available empirical analyses regarding the phenome- 
non of convergence/divergence of long-term interest rates in the European Union there is an absence of studies which concern an assessment of the contribution of particular countries to this process. The conviction of the thus far insufficient exploration of the convergence issues, in particular with regard to the impact of individual countries on this process, was the main motivation of the authors to undertake this topic.

The main objective of the empirical analysis conducted in this research is to examine the impact of individual EU member countries on the process of convergence of interest rates. In particular, we will be interested in the nature of the said impact (positive or negative), and thus the answer to the question of which countries pose the greatest risk to the cohesion process of the UE as a whole. The conducted analyses will be accompanied by an assumption of a considerable importance of the fiscal stability of a given economy in the process of convergence/divergence. Therefore, we hypothesised that the pace of changes occurring in long-term interest rates in a given country affects long-term interest rates in countries with a similar fiscal stability, measured by the ratio of public debt to GDP.

\section{Subject and Range of the Investigation}

The subject matter of the study concerns the process of convergence of long-term interest rates in the European Union in the period between January 2016 and November 2016 with the consideration of the particular impact of individual countries on this process. Due to the unavailability of data, Estonia was excluded from the analysis.

The dependent variable in the models of convergence was an increase in the spread of yield of ten-year Treasury bonds. The analyses of the relationships between the debt markets in Europe have been conducted using spreads understood as an excess in the yields expected by investors in connection with the risks incurred by them.

Due to the interest nature of debt instruments, using the rates of return from their prices could result in drawing the wrong conclusions. Yield spreads of ten-year Treasury bonds issued by the twenty-seven European economies have been calculated as the difference between the yields of government bonds issued by a given economy and the rate of return of another risk-free debt instrument, in this case the German ten-year treasury bond (see also Hull, 2011, p. 392).

The empirical analysis concerning an occurrence of the process of convergence of long-term interest rates in the European Union and establishment of the impact of individual countries on this process were carried out 
on the basis of monthly data. In order to take into account the impact of the global financial crisis and the debt crisis on the analysed phenomenon, the time range of the study was divided into two sub-periods, i.e. the period between 01.2006-12.2010 and 01.2011-11.2016. The data was obtained from the Eurostat and the World Bank databases. The calculations were performed using the R-Cran (version 3.2.5), while the drawings were prepared with the use of MapViewer.

\section{Methodology}

The verification of an occurrence of equalising levels of spreads of government bonds was based on the use of the panel data model, which takes into account individual effects (see e.g. Dańska-Borsiak, 2011; Suchecki (ed.), 2012). The said model takes the following form (FE_IND):

$$
\left[\frac{s_{i t}}{s_{i t-1}}\right]=\alpha_{i}+\beta s_{i t-1}+\varepsilon_{i t},
$$

where:

$\alpha_{i}$-individual characteristic of the issuer,

$s_{i t}$ - value of the spread of interest rate of government bonds in country $i$ in period $t$ (benchmark - Germany),

$s_{i t-1}-$ value of the spread of interest rate of government bonds in country $i$ in period $t-1$.

Model (1) was extended by introducing the connections described by the connectivity matrix based on an economic distance. The inclusion of these links modifies the formula (1) to take the following form (SAR_FE_IND):

$$
\left[\frac{s_{i t}}{s_{i t-1}}\right]=\alpha_{i}+\beta s_{i t-1}+\rho \sum_{j \neq i} w_{i j, t}\left[\frac{s_{i t}}{s_{i t-1}}\right]+\varepsilon_{i t},
$$

where:

$\rho$ - parameter constituting the average value of the effect of "neighbouring" issuers for country $i$ (the statistical significance means that there is a relation between the values of spread for a given country and the values of spread in countries with similar characteristics in terms of specific economic characteristics),

$w_{i j}$ - element of the connectivity matrix which defines the connection between country $i$ and $j$. 
For more details on the classes of models see e.g. Suchecki (ed.) (2012). The same classes of models, among others, were used in Szulc et al. (2014) and Szulc, Wleklińska (2015).

The matrix of an economic distance used in the analysis that comprises links that vary in time is a symmetric block diagonal matrix of the following form:

$$
\begin{aligned}
& \mathbf{D}^{*}=\left[d_{i j, t}^{*}\right]_{N T \times N T}=\left[\begin{array}{ccccc}
\mathbf{D}_{1}^{*} & \ldots & & & \mathbf{0} \\
\vdots & \ddots & & . & \\
& & \mathbf{D}_{t}^{*} & & \\
& \ddots & & \ddots & \vdots \\
\mathbf{0} & & & \ldots & \mathbf{D}_{T}^{*}
\end{array}\right]_{N T \times N T} \\
& \mathbf{D}_{t}^{*}=\left[d_{i j, t}^{*}\right]_{N \times N}, \text { for } t=1,2, \ldots, T .
\end{aligned}
$$

The particular elements of matrix $\mathbf{D}^{*}$ which define the economic distance between pairs of objects, in general release, can be described by the formula:

$$
d_{i j, t}^{*}=\sum_{p} \frac{1}{k_{x_{p}}+1} \sum_{r=0}^{k_{x_{p}}}\left|x_{p, i, t-r}-x_{p, j, t-r}\right|^{\delta_{x_{p}}},
$$

where:

$x_{p, i, t-r}-$ value of the variable which is the basis for the evaluation of the difference between units $i$ and $j$ in period $t-r\left(r \in\left[0, k_{x_{p}}\right]\right)$,

$k_{x_{p}}-$ value of the time lag of variable $x_{p}$,

$\delta_{x_{p}}-$ normalising parameter (along with an increase of the delta of the normalising parameter, the relationships between objects of a greater similarity grow).

In particular the determination of an economic distance between objects can be performed with the use of one variable. In the conducted study the distance was determined based on the $\frac{d e b t}{G D P}$ ratio. The ratio of debt to gross domestic product is one of the most popular indicators of fiscal stability, which was the basis for the formulation of one of the assumptions contained in the Maastricht Treaty and the Stability and Growth Pact. The elements $d_{i j, t}^{*}$ take the following form: 


$$
d_{i j, t}^{*}=\left|\frac{d e b t_{i t}}{G D P_{i t}}-\frac{d e b t_{j t}}{G D P_{j t}}\right|,
$$

where $\frac{d e b t_{i t}}{G D P_{i t}}, \frac{d e b t_{j t}}{G D P_{j t}}-$ public debt share in GDP in country $i$ and $j$ in the period $t$.

Subsequently, the components of matrix $\mathbf{D}^{*}$ should be inversed, i.e.:

$$
d_{i j, t}=\frac{1}{d_{i j, t}^{*}} \text {. }
$$

The connectivity matrix must be row standardized which means that the sum of every row should be equal to 1 . It can be obtained by the following transformation:

$$
w_{i j, t}=\frac{d_{i j, t}}{\sum_{j} d_{i j, t}} \text { for } i=1,2, \ldots, N .
$$

Then, the following assumption is true:

$$
\mathbf{W}=\left[w_{i j, t}\right]_{N T \times N T} \forall i \sum_{j=1}^{N T} w_{i j, t}=1 .
$$

The models described by the formulas (1) and (2) were used to evaluate the process of convergence/divergence of long-term interest rates in Europe. The impacts of individual states in the considered process were estimated using the theory of vertical convergence, which in its original form was complementary to the concept of income convergence. The classical models of absolute and conditional convergence did not provide the possibility to estimate individual effects of each of the objects in the process. Considering the fact that in large groups of objects, which are characterised by significant differences, both such objects exist for which the hypothesis of existence of convergence is justified and those that do not converge through the investigated characteristics, false conclusions may be drawn with regard to whether the process of convergence between all analysed objects occurs or not. The idea of vertical convergence refers essentially to the marginal credit risk which is determined as the difference between the risk calculated with regard to full loan portfolio and the portfolio consisting of $N-1$ components.

The values of vertical convergence for every issuer were obtained using the formula: 


$$
\operatorname{conv}_{i}=b-b_{N-i},
$$

where:

$b$ - speed of convergence, indicating the time necessary to equalise levels of the analysed phenomenon, wherein:

$$
b=-\frac{\ln (1+\beta)}{T},
$$

$b_{N-i}$ - speed of convergence calculated for the researched group of objects with the exception of object $i$.

Value of $\operatorname{conv}_{i}$ tells us what is the direction and strength of the influence of particular states on the process of alignment of long-term interest rates.

\section{Preliminary Data Analysis}

There is an obvious connection between the size of the public debt and deficit and the yields on long-term government bonds. The height of an interest rate of debt securities issued by the Treasury affects the pace of an increase of the debt to GDP ratio, thereby impacting the solvency of the government. The rising level of the public debt may lead to an expectation of a higher risk premium by the investors reflected in the increase in bond yields, which in turn may accelerate the pace of debt accumulation. The positive relationship between the rate of debt accumulation and its level is often referred to the economic phenomena known as "the snowball effect".

The problem of an increasing debt-to-GDP ratio and therefore the declining confidence in the countries issuing debt securities has been taken up again by the theorists of the market due to the outbreak of the global financial crisis. However, the doubts concerned with the solvency of governments grew since the crisis of the 1930s, when the fear of the consequences of many developed countries caused them to implement a highly expansionary fiscal policy leading in consequence to a sharp increase in their debt. In particular, countries belonging to what was conventionally called "the southern Europe" began to grapple with growing internal and external imbalances, which was soon reflected in the decline in demand for the bonds issued by the Treasury.

Figure 1 shows bar graphs concerning the values of the public debt of the member countries of the European Union in the period between 2006-2015. The graphs have been performed with the use of annual data. The horizontal line indicates an excess of the rate of one hundred percent of the gross domestic product. It may be noticed that at the end of the analysed period, the 
countries from the southern Europe were most affected by the debt crisis. Nevertheless, the problem of debt affected not only the countries considered to be poorer, such as Greece, Portugal, Lithuania, Latvia and Estonia, but also Ireland, whose economic indicators of the last decade were to set an example for the countries of the central and eastern Europe. Among the countries whose value of debt in the recent years has exceeded one hundred percent of the gross domestic product we have: Portugal, Belgium, Cyprus, Greece and Italy. Until 2014, Iceland belonged to this group as well, however, in 2015 the debt ratio did not exceed seventy-eight percent of GDP.

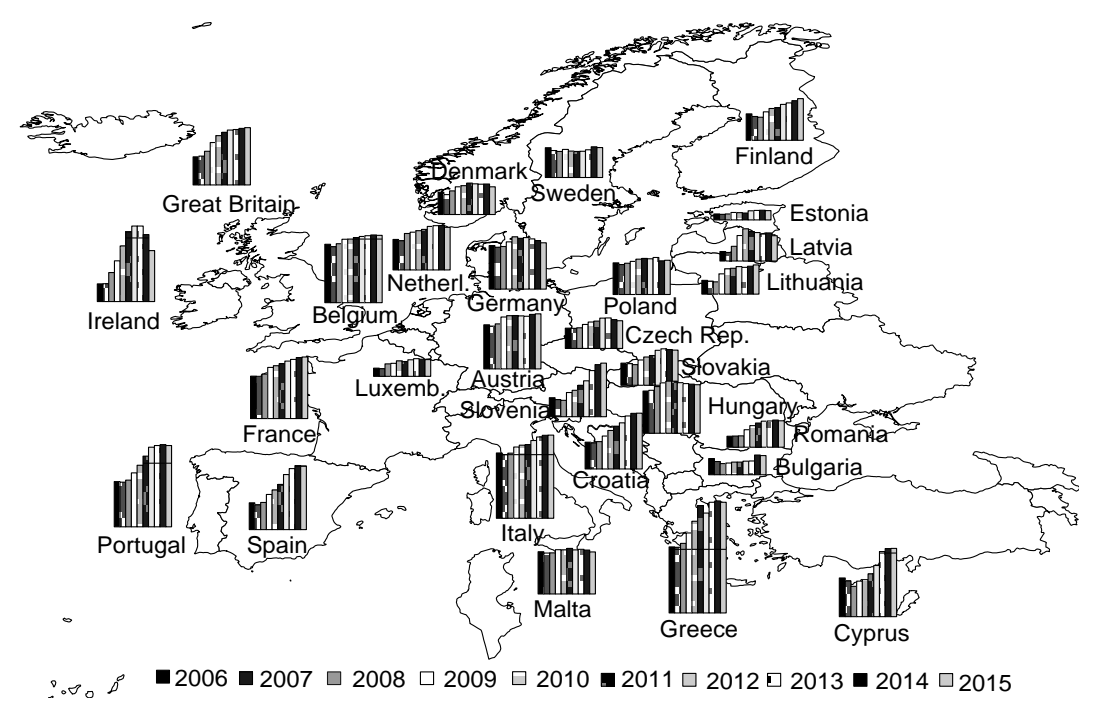

Figure 1. Bar charts of debt to GDP ratio in the years 2006-2015

In turn, Figure 2 shows bar graphs reflecting the ratio of deficit to the gross value of gross domestic product.

The rapid increase in debt is one of the main factors having a destabilizing effect on the economic system. However, along with an increase of national prosperity the level of the public debt acceptable for investors increases, though what is also not without significance is the credit history of a given country. Among the economies that faced the necessity to apply for international assistance are Romania and Latvia, which in 2010 were at risk of bankruptcy.

According to the estimates of the European Commission, Romania's public debt ratio amounted to 30.8 percent of gross domestic product, whereas budget deficit to 6.4 percent of GDP. In the case of Latvia, which has been on the map of Europe for less than twenty-five years, these indica- 
tors were 44.7 percent of GDP and 6.4 percent of GDP, respectively. In the same period, the United Kingdom, which is one of the most developed countries of the world, made use of external financing to cover the budget deficit of ten percent of the gross domestic product, with the debt level reaching 82.5 percent.

It should be noted, however, that the level of debt which is safe from the point of view of an investor and creates an incentive to invest in the bonds of a given country may suddenly change. An example would be the situation of Greece before the outbreak of the financial crisis, whose bonds were very popular among investors despite the fact that the public debt was oscillating within the range of one hundred percent of gross domestic product. The escalation of the crisis raised uncertainty among investors and as a consequence the deficit and the value of the public debt of Greece rose sharply thus discouraging investors to make further investments and bringing the country to the brink of bankruptcy.

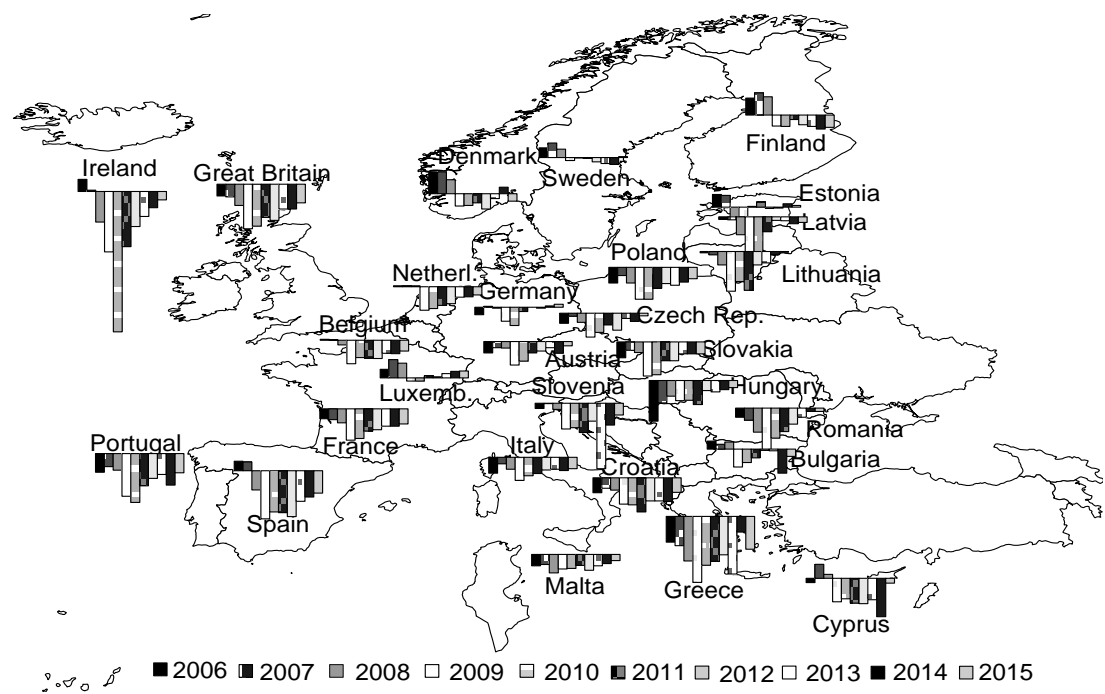

Figure 2. Bar charts of deficit to GDP ratio in the years 2006-2015

It can be concluded that if the level of indebtedness of a country exceeds one hundred percent of the gross domestic product with the ratio of the budget deficit oscillating within the range of ten percent, there is a likelihood of defaults on receivables from loans. It should be emphasized that if, on a yearly basis, a country emits bonds with a value equal to or exceeding the level of GDP and then repays them along with the interest through the issuance of new securities, as long as the rate of economic growth is higher than 
the cost of debt operation, i.e. the interest rates on the issued government bonds, this mechanism will be repeated periodically whenever such a necessity arises. This practice was used by many European economies, some of which implemented it at a significantly higher level of debt, such as Italy, Greece, and Portugal.

Figures 3 and 4 show the development of ten-year yield spreads of government bonds of the EU member states in the period between January 2006 and November 2016. As it was mentioned above, due to the unavailability of data the analysis does not include Estonia. In order to maintain sufficient transparency of the presented data included in the analysis the states are divided into two groups. The vertical line on both graphs corresponds to the temporal division into two sub-periods adopted in this study.

The behaviour of the European government bonds market in the period of 2006-2016 was determined to a large extent by an increase in the overall risk level, which occurred alongside the outbreak of the international financial crisis. The increase in the profitability of treasury bonds issued by the member countries was accompanied by an increase in their diversity. It should be noted however, that in the period preceding the outbreak of the financial crisis, the European government bonds market was seen as relatively stable. For a long time, investors did not see the signs indicating anything in the near future that would shake the foundations of the unified Europe thus leading to the debt crisis.

Starting with the collapse of the Lehman Brothers bank in September 2008, we may observe a rapid and progressive decompression of the yield spreads of ten-year bonds issued by the European economies. The solvency of each country was verified with the result of a lowering of their ratings, both several times in the period considered, as well as one-offs however by a few levels. The increase in the budget deficit in the most indebted euro zone countries such as Portugal, Italy, Ireland, Greece and Spain, and the growing borrowing needs of the public sector in these countries were reflected in the declining creditworthiness measured by a rating, as well as in the growth of profitability of bonds issued by them.

The situation in the European debt markets improved slightly in the summer of 2010, when the prices of Greek bonds slightly rose, which meant a reduction in their spreads in relation to German securities. It was expected that the system procedures of the European Union and the global initiatives taken by the G-20 are starting to deliver the expected results and have a calming effect on the international financial market. Since the beginning of 2011, however, the crisis has entered a new phase leading to a continuous 
increase in the spreads of Irish and Portuguese bonds. Similarly, the profitability of Greek ten-year bonds has clearly increased.

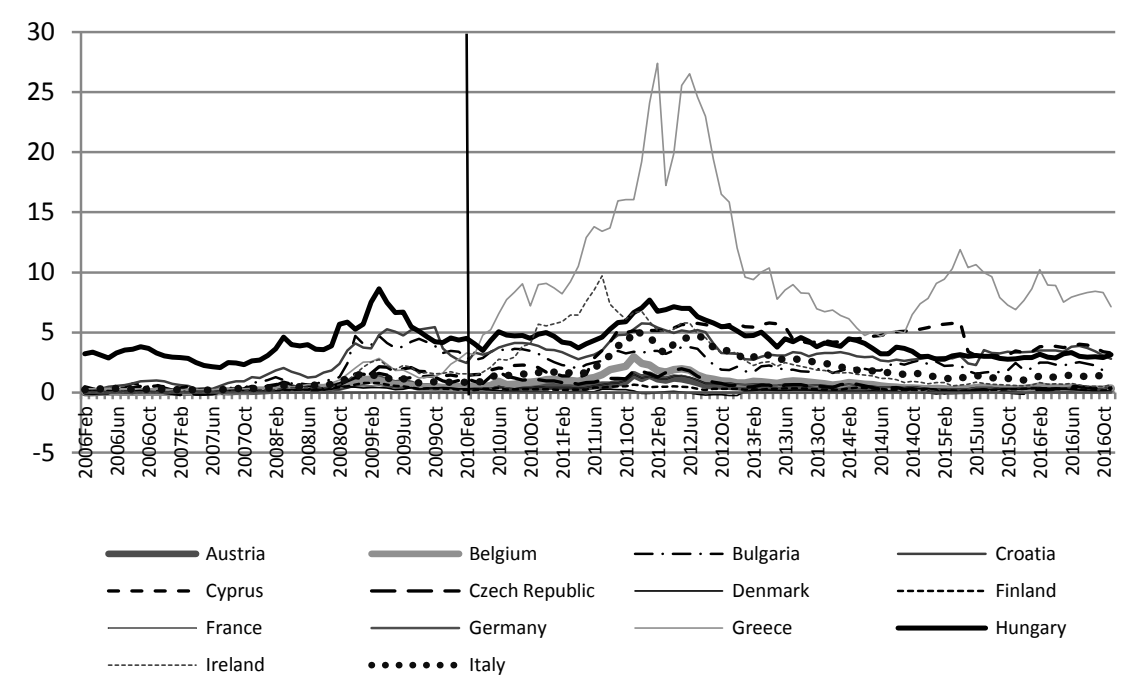

Figure 3. Yield spread of ten-year government bond of selected European Union member states in the period between 01.2006-11.2016

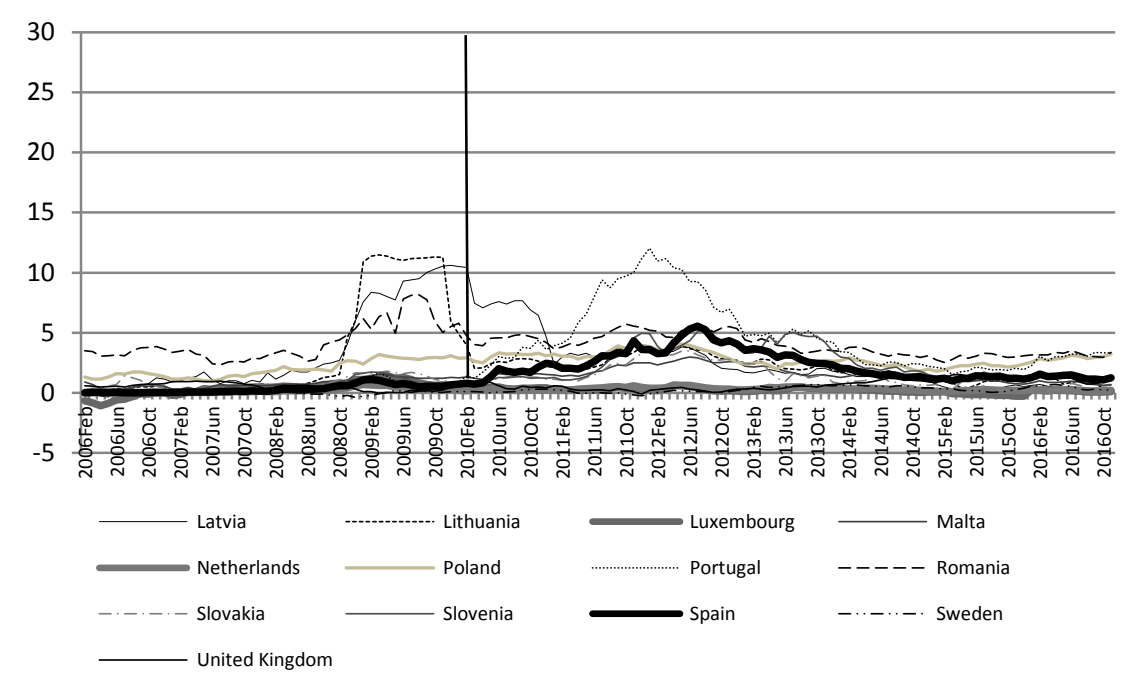

Figure 4. Yield spread of ten-year government bond of selected European Union member states in the period between 01.2006-11.2016 (cont.)

Dynamic EConometric Models 16 (2016) 165-187 


\section{Results of the Econometric Analysis}

The models given by the formulas (1) and (2) have been estimated and verified for two separate periods: the period covering the outbreak of the global financial crisis, i.e. $01.2006-12.2010$ and the "post-crisis" period between 01.2011-11.2016. The results obtained for the first period are shown in Table 1, while Table 2 contains results for the second period. The value of $\beta$ parameter for the panel data model with individual effects, which was estimated for the first period, points that the levels of spreads of ten-year treasury bonds issued by the European economies equalise through time. Since this parameter is statistically significant, it can be concluded that the member states of the European Union have implemented one of the most important principles contained in the Treaty of Maastricht that concern the convergence of economies.

Table 1. Results of the estimation and verification of FE_IND and SAR_FE_IND models for all analysed issuers in the period between 01.2006-12.2010

\begin{tabular}{ccc}
\hline Parameters & \multicolumn{2}{c}{ Models } \\
\cline { 2 - 3 } & FE_IND & SAR_FE_IND \\
\hline$\beta$ & -0.0876 & -0.0057 \\
& $(0.0068)$ & $(0.8126)$ \\
& - & 0.0697 \\
Autocorrelation of residuals & $0.0630)$ \\
Moran test & -0.0236 & -0.0077 \\
Speed of convergence & $(0.9386)$ & $(0.6807)$ \\
\hline Spen & 0.0019 & 0.0001 \\
\hline
\end{tabular}

Note: Numbers in brackets refer to the p-values. All calculations were performed with $\mathrm{R}$ - version 3.2.5.

The inclusion of the connectivity matrix, which was defined based on differences between countries in terms of the ratio $\frac{d e b t}{G D P}$, causes a reduction in value of $\beta$ parameter and at the same time causes it to lose its statistical significance. Therefore, the study, which takes into account the spatial relations between economies which are quantified on the basis of the debt ratio would lead to the conclusion of an absence of a process of convergence of interest rates of government bonds in period I. Interestingly, however, parameter $\rho$ in the SAR_FE_IND model proved to be statistically insignificant. This demonstrates a lack of dependence between the pace of changes in the interest rates of government bonds in one country and their paces in countries with a similar financial stability, i.e. in countries with a similar share of debt in gross domestic product. If so, the preferred model in this analysis, should be the FE_IND model without spatial effects. 
During the period between 01.2011-11.2016 the $\beta$ parameter in the FE_IND model remains negative, however, it is statistically insignificant, thus it should be concluded that the European Union faces a process of decompression of long-term interest rates. Changes in the profitability of government bond yields during this period were caused by a differentiated risk of insolvency of issuers, which was basically caused by ineffective, with regard to stability and growth, national fiscal and structural policies in many countries and also, in some way, by investors' speculations. The said period reveals heterogeneity of the European Union, which departs from the criteria of an optimal currency area. In the conditions of an escalating debt crisis in Europe, the common monetary policy for entire territory has not been able to equally impact on the economic situation of all individual countries.

The introduction of spatial dependencies to the model applied for the second period turns out to be an appropriate approach as the parameter $\rho$ in this case is statistically significant. It can be concluded that during the economic downturn the differences in the debt play a greater role in explaining the formation of the levels of spreads in government bond yields. Interestingly, in the SAR_FE_IND model the parameter $\beta$ is positive. It indicates a process opposite to that equalising the levels of spreads in the second period. In this case we should rather speak of a divergence and a deepening diversification of spreads of government bonds in the EU countries.

Table 2. Results of the estimation and verification of FE_IND and SAR_FE_IND models for all analysed issuers in the period between 01.2011-11.2016

\begin{tabular}{ccc}
\hline \multirow{2}{*}{ Parameters } & \multicolumn{2}{c}{ Models } \\
\cline { 2 - 3 } & FE_IND & SAR_FE_IND \\
\hline$\beta$ & -0.0087 & 0.0084 \\
& $(0.1072)$ & $(0.0143)$ \\
& - & 0.2231 \\
& & $(0.0000)$ \\
\hline Autocorrelation of residuals & -0.0682 & -0.0162 \\
Moran test & $(1.0000)$ & $0.8948)$ \\
\hline Speed of convergence & 0.0001 & -0.0001 \\
\hline
\end{tabular}

Note: Numbers in brackets refer to the p-values. All calculations were performed with $\mathrm{R}$ - version 3.2.5.

The approach presented in the methodology as the vertical convergence enables an assessment of the impact of particular issuers on the analysed phenomenon. The numerical values contained in Table 3 indicate an individual effect of each of the considered countries in the process of convergence/divergence in models (1) and (2) in both studied periods. 
Table 2. The values of vertical convergence for FE_IND and SAR_FE_IND models in the two analysed periods between $01.2006-12.2010$ (period I) and 01.2011-11.2016 (period II)

\begin{tabular}{ccccc}
\hline Country & FE_IND I & SAR_FE_IND I & FE_IND II & SAR_FE_IND II \\
\hline Austria & $-1.978 E-04$ & $-2.931 \mathrm{E}-05$ & $1.837 \mathrm{E}-06$ & $-1.162 \mathrm{E}-05$ \\
Belgium & $-1.966 \mathrm{E}-05$ & $-1.373 \mathrm{E}-05$ & $-6.786 \mathrm{E}-06$ & $-2.258 \mathrm{E}-05$ \\
Bulgaria & $-9.050 \mathrm{E}-05$ & $2.743 \mathrm{E}-05$ & $7.330 \mathrm{E}-06$ & $-6.546 \mathrm{E}-06$ \\
Croatia & $-1.092 \mathrm{E}-05$ & $2.093 \mathrm{E}-05$ & $7.062 \mathrm{E}-06$ & $-6.544 \mathrm{E}-06$ \\
Cyprus & $-7.016 \mathrm{E}-05$ & $4.153 \mathrm{E}-05$ & $1.372 \mathrm{E}-06$ & $-9.359 \mathrm{E}-06$ \\
Czech Republic & $-1.058 \mathrm{E}-04$ & $4.999 \mathrm{E}-05$ & $4.723 \mathrm{E}-06$ & $-8.369 \mathrm{E}-06$ \\
Denmark & $-4.643 \mathrm{E}-05$ & $4.003 \mathrm{E}-05$ & $-2.431 \mathrm{E}-06$ & $-1.194 \mathrm{E}-05$ \\
Finland & $2.581 \mathrm{E}-05$ & $4.348 \mathrm{E}-05$ & $-3.075 \mathrm{E}-06$ & $-1.295 \mathrm{E}-05$ \\
France & $-5.015 \mathrm{E}-05$ & $1.183 \mathrm{E}-05$ & $1.137 \mathrm{E}-06$ & $-1.392 \mathrm{E}-05$ \\
Germany & $-2.993 \mathrm{E}-05$ & $4.352 \mathrm{E}-05$ & $-7.202 \mathrm{E}-06$ & $-1.506 \mathrm{E}-05$ \\
Greece & $-1.959 \mathrm{E}-06$ & $4.175 \mathrm{E}-05$ & $-4.328 \mathrm{E}-06$ & $-1.269 \mathrm{E}-05$ \\
Hungary & $-5.007 \mathrm{E}-05$ & $4.342 \mathrm{E}-05$ & $-1.099 \mathrm{E}-06$ & $-2.193 \mathrm{E}-05$ \\
Ireland & $-1.055 \mathrm{E}-04$ & $4.446 \mathrm{E}-05$ & $7.484 \mathrm{E}-06$ & $-7.521 \mathrm{E}-06$ \\
Italy & $-1.994 \mathrm{E}-04$ & $3.473 \mathrm{E}-05$ & $4.399 \mathrm{E}-06$ & $-1.430 \mathrm{E}-05$ \\
Latvia & $1.278 \mathrm{E}-05$ & $1.625 \mathrm{E}-05$ & $-4.330 \mathrm{E}-06$ & $-1.898 \mathrm{E}-05$ \\
Lithuania & $-5.970 \mathrm{E}-05$ & $4.099 \mathrm{E}-05$ & $-2.743 \mathrm{E}-06$ & $-2.149 \mathrm{E}-05$ \\
Luxembourg & $-1.156 \mathrm{E}-04$ & $4.155 \mathrm{E}-05$ & $2.912 \mathrm{E}-06$ & $-1.528 \mathrm{E}-05$ \\
Malta & $5.281 \mathrm{E}-05$ & $4.570 \mathrm{E}-05$ & $-1.051 \mathrm{E}-05$ & $-1.770 \mathrm{E}-05$ \\
Netherlands & $-1.004 \mathrm{E}-05$ & $4.564 \mathrm{E}-05$ & $6.585 \mathrm{E}-07$ & $-9.869 \mathrm{E}-06$ \\
Poland & $1.101 \mathrm{E}-06$ & $4.460 \mathrm{E}-05$ & $5.809 \mathrm{E}-06$ & $-4.258 \mathrm{E}-06$ \\
Portugal & $-2.333 \mathrm{E}-04$ & $6.394 \mathrm{E}-05$ & $-4.054 \mathrm{E}-06$ & $-1.903 \mathrm{E}-05$ \\
Romania & $1.332 \mathrm{E}-04$ & $7.529 \mathrm{E}-05$ & $-8.785 \mathrm{E}-06$ & $-1.276 \mathrm{E}-05$ \\
Slovakia & $2.929 \mathrm{E}-04$ & $6.739 \mathrm{E}-05$ & $-1.359 \mathrm{E}-05$ & $-1.192 \mathrm{E}-05$ \\
Slovenia & $1.139 \mathrm{E}-03$ & $2.103 \mathrm{E}-04$ & $4.256 \mathrm{E}-06$ & $-1.574 \mathrm{E}-05$ \\
Spain & $-7.314 \mathrm{E}-05$ & $2.755 \mathrm{E}-05$ & $2.164 \mathrm{E}-06$ & $-6.340 \mathrm{E}-06$ \\
Sweden & $-2.921 \mathrm{E}-05$ & $3.759 \mathrm{E}-05$ & $1.405 \mathrm{E}-05$ & $-1.355 \mathrm{E}-05$ \\
United Kingdom & $-1.308 \mathrm{E}-04$ & $3.421 \mathrm{E}-05$ & $4.641 \mathrm{E}-06$ & $-1.006 \mathrm{E}-05$ \\
\hline & & & &
\end{tabular}

Figure 5 shows the influence of particular countries issuing ten-year bonds on the convergence of long-term interest rates resulting from the model (1) in period I. The positive effects are visible only in several countries, 
mainly those located in Eastern Europe (Finland, Latvia, Malta, Poland, Romania, Slovakia, Slovenia).

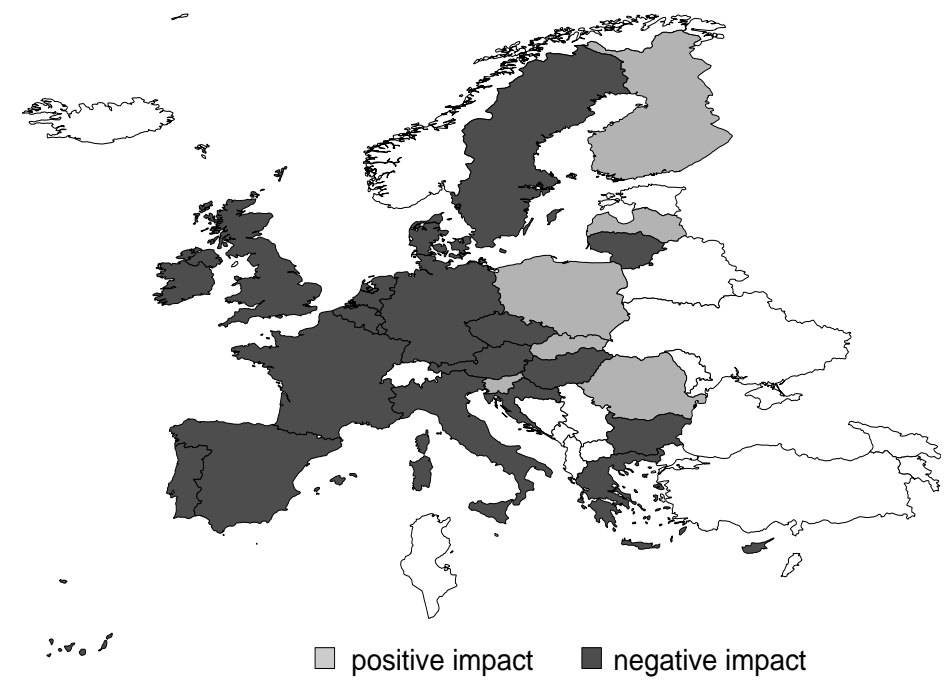

Figure 5. The impact of individual countries on the process of equalisation of spreads of government bonds in the period between 01.2006-12.2010 (FE_IND)

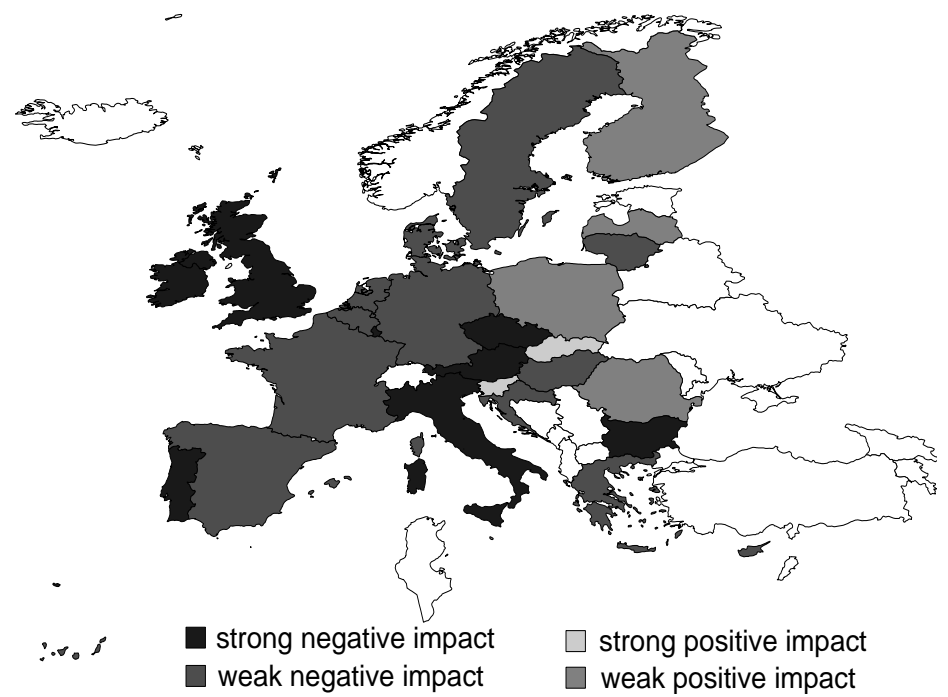

Figure 6. The distribution of values of vertical convergence of spreads of government bonds in the period between 01.2006-12.2010 (FE_IND) 
Figure 6 is a graphic illustration of the distribution of vertical convergence indicators divided into four classes. The areas marked in black and the brightest grey are characterized by high (above average) negative and positive values of the index, respectively. Similarly, areas marked in a darker grey colour and a slightly lighter grey are characterised by low (not exceeding the average) negative and positive values. The corresponding pairs of maps show results for subsequent analysed regimes differentiated by model form and time (see Fig. 7-12).

The strongest negative impact on the convergence process of long-term interest rates in the period between 01.2006-12.2010 is observed in such countries as Portugal, the United Kingdom, Ireland, the Czech Republic, Italy, Austria and Bulgaria. With the exception of the Czech Republic and Bulgaria, these are the countries where the debt ratio considerably exceeded 60 percent of GDP. The massively activated automatic stabilisers and the introduction of packages whose purpose was to stimulate the economic growth in order to maintain, at all cost, the current level of global demand, ultimately led to an abrupt increase in debt and budget deficits. The biggest surprise is the presence of Ireland in this group, which in the years between 2000-2007 could pass as a role model for other European economies.

Figures 7 and 8 are concerned with the SAR_FE_IND model for the period between 01.2006-12.2010. In the case of such a model approach, we may speak of a positive impact of the majority of countries on the analysed process. However, due to the poor quality of the current model, which was mentioned above, these results should be considered with caution.

In turn, Figures 9 and 10 show the results obtained on the basis of a panel data model with individual effects for period II. In this case, it can be noted that in the period between 01.2011-11.2016 there is a decrease in the number of countries adversely affecting the process of convergence of longterm interest rates. Paradoxically, the $\beta$ parameter in the considered model turns out to be statistically insignificant, and, thereby, does not confirm an occurrence of the analysed phenomenon of convergence.

The results of analysis of vertical convergence for the model which takes into account the dependencies based on the share of debt in GDP for the second researched period are shown in Figures 11 and 12. It should be noted that in this case all the countries have a negative (some greater, other smaller - see Figure 12) effect on the alignment process of bond yields. As it was mentioned earlier, it is not surprising that instead of convergence we may in fact be looking at the divergence process. 


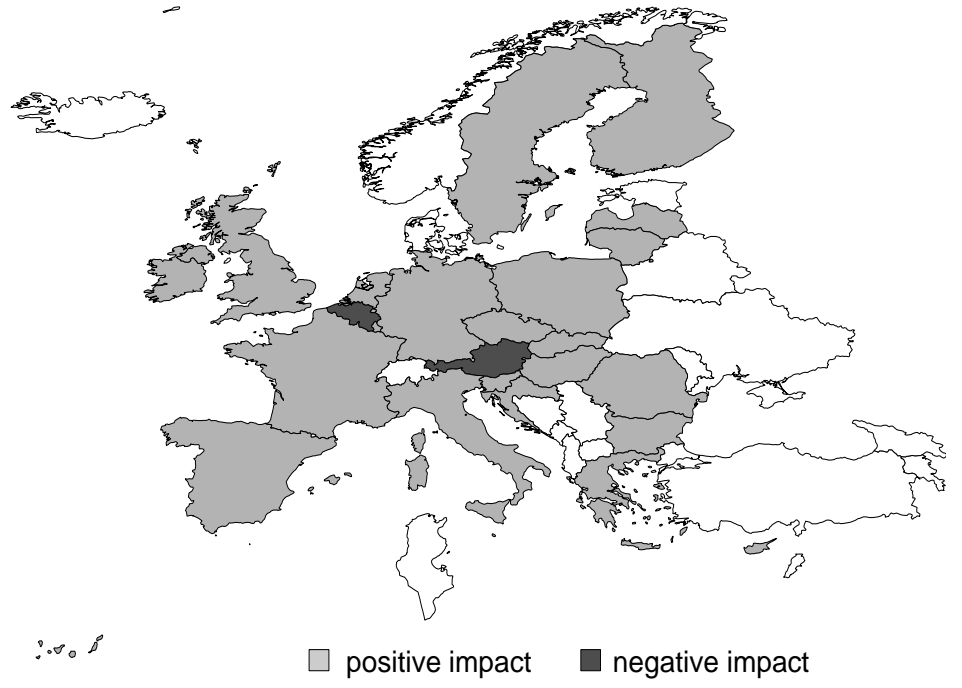

Figure 7. The impact of individual countries on the process of equalisation of spreads of government bonds in the period between 01.2006-12.2010 (SAR_FE_IND)

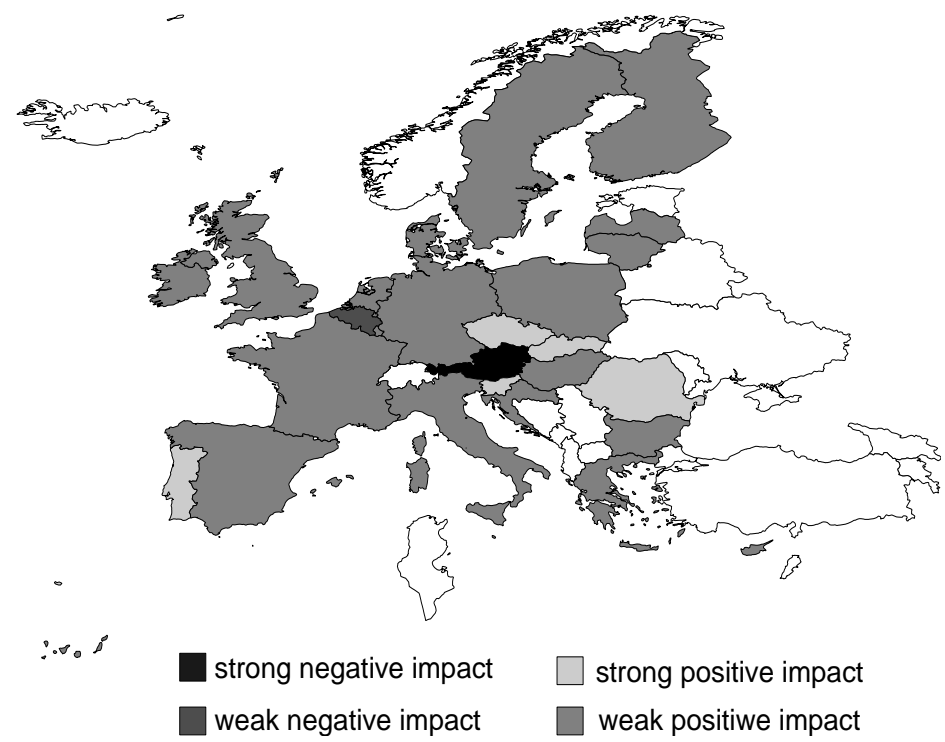

Figure 8. The distribution of values of vertical convergence of spreads of government bonds in the period between 01.2006-12.2010 (SAR_FE_IND)

Dynamic EConometric Models 16 (2016) 165-187 


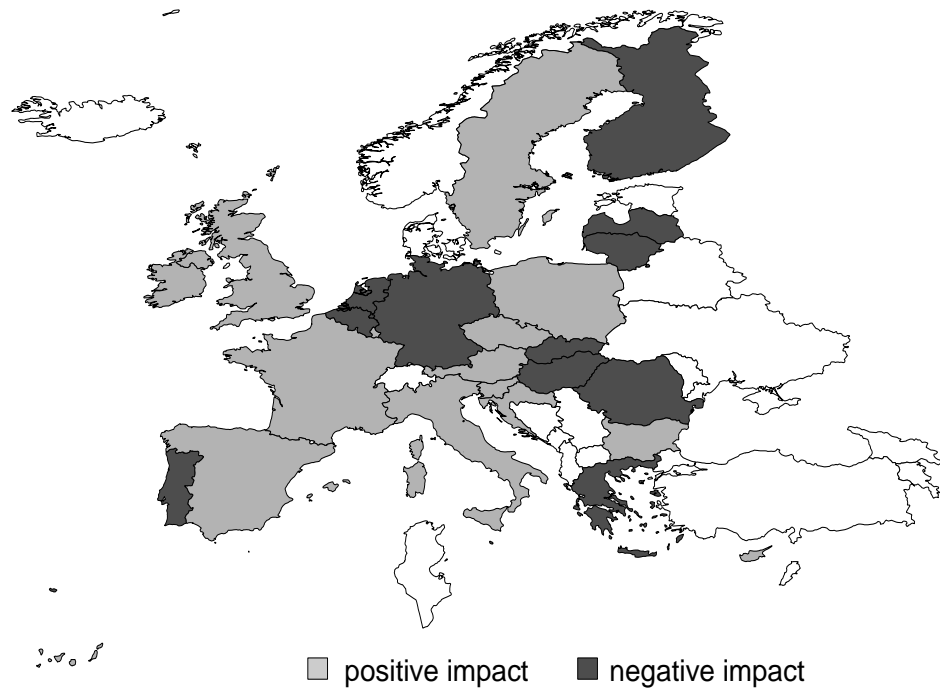

Figure 9. The impact of individual countries on the process of equalisation of spreads of government bonds in the period between 01.2011-11.2016 (FE_IND)

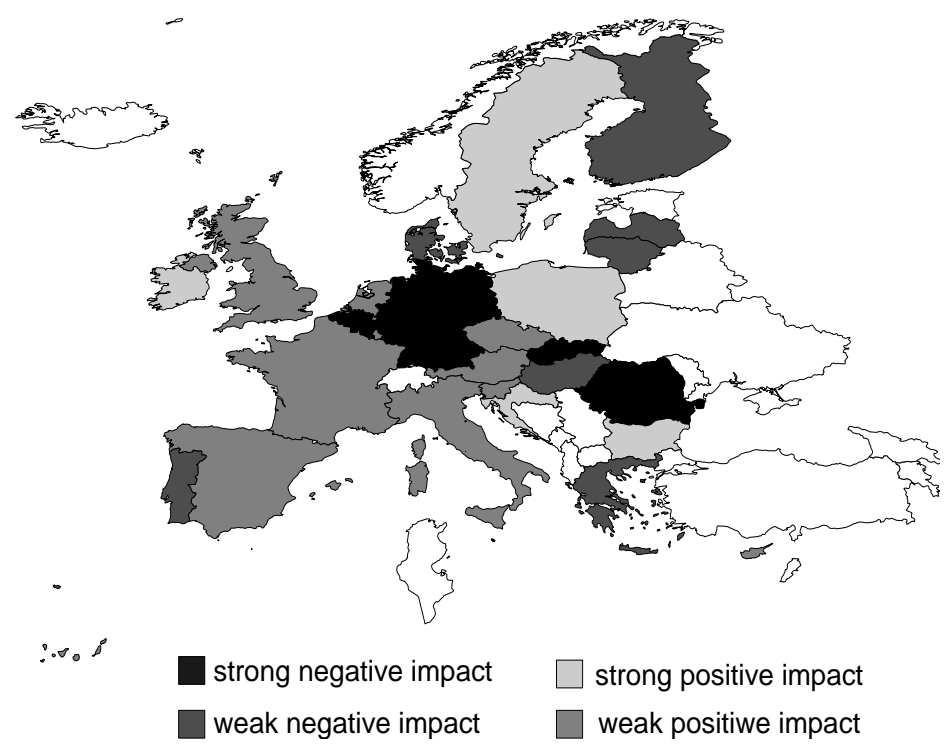

Figure 10. The distribution of values of vertical convergence of spreads of government bonds in the period between 01.2011-11.2016 (FE_IND) 


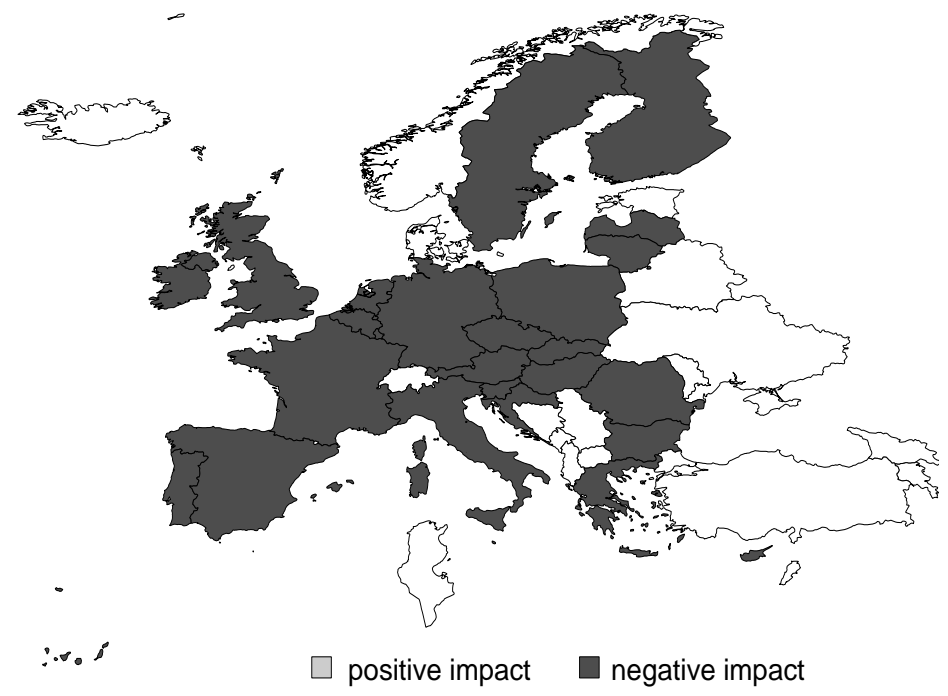

Figure 11. The impact of individual countries on the process of equalisation of spreads of government bonds in the period between 01.2011-11.2016 (SAR_FE_IND)

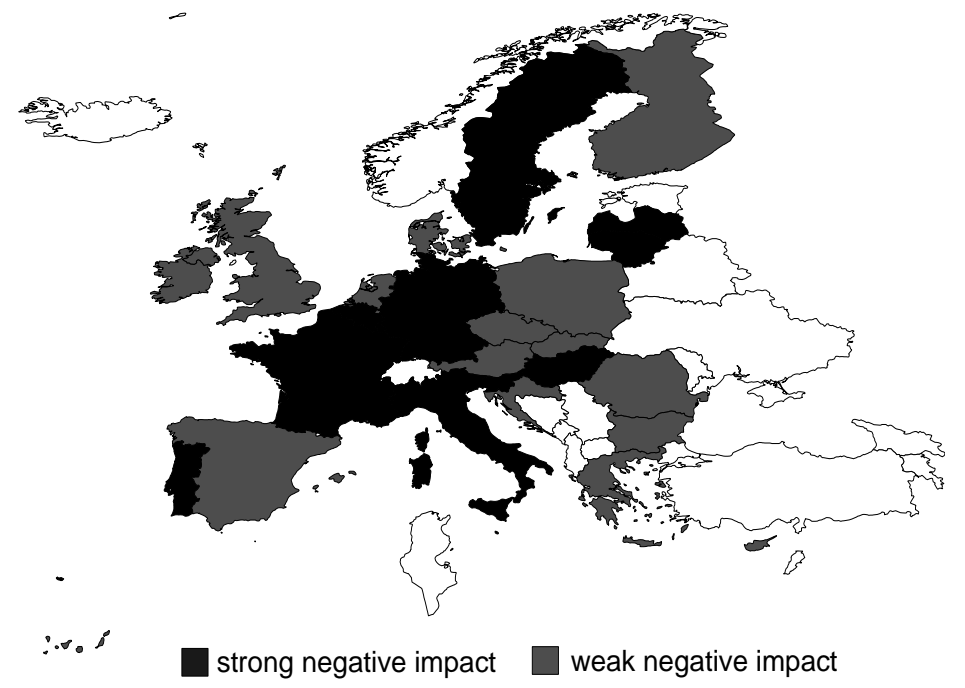

Figure 12. The distribution of values of vertical convergence of spreads of government bonds in the period between 01.2011-11.2016 (SAR_FE_IND) 


\section{Conclusions}

The global financial crisis and the debt crisis in the European Union has had a severe impact on many economic processes taking place in the world. The recession tensions increasing in the global and European economy significantly affected the convergence of long-term interest rates, which is reflected by the state of public finances and the business cycle. At the root of the increasing divergence observed in the analysed period there are different approaches to fiscal policy and significant discrepancies concerning the state of the public finances of European economies.

The aim of the study was to identify the impact of individual EU member countries on the processes of convergence/divergence of long-term interest rates. Empirical analyses provide a clear evidence that in the first analysed sub-period i.e. between 01.2006-12.2010 the divergence in yield spreads of ten-year Treasury bonds issued by the European economies were reduced, as evidenced by statistically significant and negative $\beta$ parameter. However, given the fact that during this period a vast majority of the EU member states was characterised by a negative impact on the process of convergence of long-term interest rates, it is likely that the justification of the significance and the negative value of $\beta$ parameter, may be the fact of fulfillment of the convergence criteria during the introduction of euro into the circulation, i.e. in 2002 as well as in the first years of its operation. Probably the high rate of convergence in the period preceding the time span of the analysis carried out in this article enabled maintenance of the desired properties of the convergence coefficient, despite the fact of an occurrence of a destimulating effect of most economies on the process of convergence of interest rates.

The properties of the spatial model of convergence of ten-year Treasury bonds estimated for the first period do not allow confirmation of the hypothesis concerning the fact that the pace of changes of long-term interest rates in a given country affect long-term interest rates in countries with a similar fiscal stability, measured by the ratio of public debt to GDP. The same model estimated for the second period leads to a different conclusion, namely such that confirms the hypothesis adopted in the paper.

In the period between 1.2011-11.2016 the differences in debt played a significant role in explaining the formation of the levels of spreads in government bond yields. The interest rates dictated by the European Central Bank exerted a varying impact on the economic situation of particular economies, thus leading only to an increase in the heterogeneity of the European 
Union, with the result that in relation to that period it is appropriate to speak of a move towards divergence of interest rates in the Community.

In order to confirm these suppositions the research should be continued with consideration of an extended time span of the analysis to take into account the period of adoption of the euro.

\section{References}

Adam, K., Jappelli, T., Menichini, A., Paduka, M., Pagano, M. (2002), Analyse, compare, and apply alternative indicators and monitoring methodologies to measure the evolution of capital market integration in the European Union, Centre for Studies in Economics and Finance, University of Salerno, http://europa.eu.int/comm/internal_market/en/update/economicreform/020128_ cap_mark_int_en.pdf Alary and Gollier.

Afonso, A., Arghyrou, M., Kontonikas, M. (2012), The Determinants of Sovereign Bond Yield Spreads in the EMU, European Central Bank, ISEG Economics Working Paper. https://www.ecb.europa.eu/pub/pdf/scpwps/ecbwp1781.en.pdf?7a5b97c0f1475221387 50dacb92a6f5a, DOI: http://dx.doi.org/10.2139/ssrn.2223140.

Attinasi, G. M., Checherita-Westphal, C. D., Nickel, C. (2009), What explains the surge in euro area sovereign spreads during the financial crisis of 2007-09?, European Central Bank, Working Paper Series No. 1131, https://www.ecb.europa.eu/pub/pdf/scpwps/ecbwp1131.pdf?57b2f4d1d575836598a0a $7461 \mathrm{ab} 62 \mathrm{fb} 2$.

Baele, L., Ferrando, A., Hordahl, P., Krylova, E., Monnet, C. (2004), Measuring Financial Integration in the Euro Area, European Central Bank, Occasional Paper Series No. 14. https://www.ecb.europa.eu/pub/pdf/scpops/ecbocp14.pdf.

Barrios, S., Iversen, P., Lewandowska, M., Setzer, R., (2009), Determinants of intra-euro area government bond spreads during the financial crisis, European Economy - Economic Papers 388, Directorate General Economic and Monetary Affairs (DG ECFIN), European Commission, http://ec.europa.eu/economy_finance/publications/pages/publication16255_en.pdf

Blanchard, O. J. (1990), Suggestions for a New Set of Fiscal Indicators, OECD Department of Economics and Statistics, Working Papers No. 79. http://www.oecdilibrary.org/docserver/download/435618162862.pdf?expires=1486293 197\&id=id\&accname $=$ guest $\&$ checksum $=$ AF14F773911104F2524C88633050C373, DOI: http:// dx.doi.org/10.1787/435618162862.

Buiter, W. H. (2006), The "Sense and Nonsense of Maastricht" Revisited: What Have We Learnt about Stabilization in EMU?, Journal of Common Market Studies, 44(4), 687-710, DOI: http://dx.doi.org/10.1111/j.1468-5965.2006.00658.x.

Dańska-Borsiak, B. (2011), Dynamiczne Modele Panelowe w Badaniach Ekonomicznych (Dynamic Panel Models in Economic Research), Wydawnictwo Uniwersytetu Lódzkiego, Łódź.

Hull, J. (2011), Zarządzanie ryzykiem instytucji finansowych (Risk Management of Financial Institutions), PWN, Warszawa.

Klepsch, C., Wollmershauser, T. (2011), Yield Spreads on EMU Government Bonds - How the Financial Crisis Has Helped Investors to Rediscover Risk, Economic Trends, 46(3), 169-176, DOI: http://dx.doi.org/10.1007/s10272-011-0379-2. 
Lane, P. R. (2012), The European Sovereign Debt Crisis, Journal of Economic Perspectives, 49-68, DOI: http://dx.doi.org/10.1257/jep.26.3.49.

Marchewka-Bartkowiak, K. (2008), Zarzadzanie dlugiem publicznym. Teoria i praktyka państw Unii Europejskiej (Management of public debt. Theory and practice of the EU countries), PWN, Warszawa.

Nowak, W. (2007) Konwergencja $w$ modelach endogenicznego wzrostu gospodarczego (Convergence in the models of endogenous growth), Kolonia Limited, Wrocław.

Pagano, M., von Thadden, E. L. (2004), The European Bond Markets Under EMU, Oxford Review of Economic Policy, 20(4), 531-554, DOI: http://dx.doi.org/10.1093/oxrep/grh031.

Pełka, W. (2008), Konwergencja monetarna jako warunek wzrostu gospodarczego w nowych krajach członkowskich Unii Europejskiej (Monetary convergence as a condition for economic growth in the new member countries the European Union), in PancerCybulska E. (ed.), Spójność spoteczna, gospodarcza i terytorialna w polityce Unii Europejskiej (Social, economic and territorial cohesion in the European Union Policy), Wydawnictwo Uniwersytetu Ekonomicznego, Wrocław, 270-289.

Suchecki, B. (ed.) (2012), Ekonometria przestrzenna II. Modele zaawansowane (Spatial Econometrics II. Advanced Models), Wydawnictwo C.H.Beck, Warszawa.

Szulc, E., Wleklińska, D., Górna, K., Górna, J. (2014), The Significance of Distance Between Stock Exchanges Undergoing the Process of Convergence: an Analysis of Selected World Stock Exchanges During the Period of 2004-2012, Dynamic Econometric Models, 14, 125-144, DOI: http://dx.doi.org/10.12775/DEM.2014.007.

Szulc, E., Wleklińska, D. (2015), Spatio-temporal analysis of convergence of development level of selected stock exchanges in the period of 2004-2012, Dynamic Econometrics Models, 15, 5-26, DOI: http://dx.doi.org/10.12775/DEM.2015.001.

\section{Udział gospodarek europejskich w procesie zbieżności długoterminowych stóp procentowych w UE w okresie 2006-2016}

$\mathrm{Z}$ a r y s t re śc i. Artykuł dotyczy procesu zbieżności stóp procentowych dziesięcioletnich obligacji skarbowych krajów UE. Stanowi on próbę oceny udziału poszczególnych gospodarek europejskich $\mathrm{w}$ tym procesie $\mathrm{z}$ wykorzystaniem koncepcji tzw. konwergencji pionowej. Podstawowym narzędziem analizy były modele panelowe $\mathrm{z}$ ustalonymi efektami, w tym modele uwzględniające powiązania między gospodarkami, kwantyfikowane za pomocą macierzy odległości między wskaźnikami stabilności fiskalnej, jako udział długu publicznego w PKB. Analizę przeprowadzono dla 27 krajów członkowskich UE w okresie styczeń 2006listopad 2016.

S łow a kluczowe: długoterminowe stopy procentowe, proces zbieżności, stabilność fiskalna, modele panelowe, macierz powiązań ekonomicznych. 